\title{
Competitive Advantages of Small Medium Industry on the Islands in Indonesian Context
}

\author{
Muslim El Hakim Kurniawan, Gatot Yudoko, Mursyid Hasan Basri \\ School of Business and Management, Institut Teknologi Bandung, Bandung, Indonesia
}

\begin{tabular}{|c|c|}
\hline ARTICLE INFO & A B S T R A C T \\
\hline $\begin{array}{l}\text { Keywords: } \\
\text { competitiveadvantage, } \\
\text { small medium industry, } \\
\text { islands, } \\
\text { Indonesia, } \\
\text { government }\end{array}$ & $\begin{array}{l}\text { Indonesian Law No. } 3 / 2014 \text { regarding Industry requires both Central } \\
\text { and Local Governments to realize the competitiveness of small and } \\
\text { medium industries. However, the fact that the condition of each } \\
\text { region is not similar becomes a main problem. It is because Indonesia } \\
\text { is an archipelagic country. The competitiveness index of Asia } \\
\text { Competitiveness Institute } 2015 \text { indicates that islands provinces, such } \\
\text { as Kepulauan Bangka Belitung, Nusa Tenggara Barat, Nusa Tenggara } \\
\text { Timur, Sulawesi Utara, Maluku, Maluku Utara, Sulawesi Tenggara, need } \\
\text { specific development strategies. They cannot be equated with the } \\
\text { mainlands, such as Java and Sumatera, because their competitiveness } \\
\text { rank is very low. A review of literature on the competitiveness of } \\
\text { islands entrepreneurs shows that from the } 4 \text { (four) schools of thought } \\
\text { in competitive advantage, only few researchers have pertained on the } \\
\text { knowledge based on the schools of thought. Therefore, this could be a } \\
\text { future research opportunity. }\end{array}$ \\
\hline
\end{tabular}

SARI PATI

Undang-undang nomor 3 tahun 2014 tentang perindustrian mengharuskan pemerintah baik di pusat maupun di daerah untuk mewujudkan industri kecil menengah yang berdaya saing. Namun, faktanya kondisi tiap-tiap daerah di Indonesia tidaklah sama, hal ini salah satunya dikarenakan Indonesia adalah negara kepulauan. Asia Competitiveness Institute pada tahun 2015 mengeluarkan temuan tentang daya saing provinsi di Indonesia dan hampir semua provinsi kepulauan seperti Kepulauan Bangka Belitung, NTT, NTB, Sulawesi Utara, Sulawesi Tenggara, Maluku dan Maluku utara jauh lebih rendah dari provinsi daratan. Literature review mengenai daya saing wirausahawan di daerah kepulauan menunjukkan bahwa dari 4 dasar pemikiran sumber daya saing, hanya sedikit peneliti yang mengemukakan bahwa knowledge based yang menjadi dasar kesuksesan, dan hal ini merupakan peluang untuk penelitian lebih lanjut. 


\section{INTRODUCTION}

Indonesian Law No.3/2014 regarding industry, article 72 clause 1 states that the Central Government and/or Local Governments grow and develop small and medium industries (SMI) to realize their competitiveness, so that they have an important role in the development of the national industry and in the alleviation of poverty through the expansion of employment opportunities, and produce goods and/or services for export industries. Further, it is mentioned that to realize the small and medium industries, the Government shall formulate policies and strengthen the organization capacity and provision of facilities. Based on the vision, there are two main responsibilities of the Governments, which are to grow SMI and to develop the competitiveness. Despite the undisputable role of SMI in the economy such as absorbing 9.7 million employees nationally in 2013, to improve the competitiveness of small and medium industries faces a lot of challenges. In addition to productivity-related matters, some other challenges are related to complacent (satisfied with their current level) (Cromie, Dunn, Sproull, \& Chalmers, 2001) or feeling like a 'big fish in a little sea' (Švárová \& Vrchota, 2014).The challenges will be more severe, if the context is narrowed down to islands level. Although Indonesia is an archipelagic country with 17.000 islands, there are only eight provinces which are established as islands provinces (nasional.kontan,2017). It is assumed that, generally, the islands provinces face more difficult challenges than those in the mainlands (e.g. Java and Sumatra). Small size and geographical remoteness are commonly regarded as sources of economic helplessness which might unfavorably affect economic development and performance (Baldacchino, 2005). Data of Asia Competitiveness Institute 2015 (Than, Amri, Merdikawati, \& Ahmad,2017) indicate that majority the Indonesian 8 (eight) islands provinces have lower competitiveness compared to provinces in the mainlands as shown in table 1.

4 (four) scores considered in the scheming of this competitiveness index is the financial condition, business and labor; government and institutional planning; macroeconomic stability; and life quality and infrastructure development (Than, Amri, Merdikawati, \& Ahmad, 2017). This condition affects the exertion to grow and development of small medium industries in the islands twice harder than the mainland. On the other hand, the economy in the islands is getting worse because they usually rely on their economy in natural resources such as mining, nonetheless, environmental issues and reduced reserves of natural resources are making their economies worse off. Some research about small medium industry development in islands found that so many perceived hurdles such as limited technical expertise, inadequate sales level, high operating

Table 1. Indonesia Provinces Competitiveness Rank 2015 (Than, et al. 2017)

\begin{tabular}{cccc}
\hline Islands Provinces & $\begin{array}{c}\text { Competitiveness Rank } \\
\text { from 33 Provinces }\end{array}$ & $\begin{array}{c}\text { Mainland } \\
\text { Provinces }\end{array}$ & $\begin{array}{c}\text { Competitiveness Rank } \\
\text { from 33 Provinces }\end{array}$ \\
\hline Kepulauan Bangka Belitung & 30 & DKI Jakarta & 1 \\
\hline Kepulauan Riau & 7 & Jawa Timur & 2 \\
\hline Nusa Tenggara Timur & 32 & Kalimantan Timur & 3 \\
\hline Nusa Tenggara Barat & 26 & Jawa Barat & 4 \\
\hline Sulawesi Utara & 11 & Jawa Tengah & 5 \\
\hline Maluku & 29 & D.I. Yogyakarta & 6 \\
\hline Maluku Utara & 31 & - & - \\
\hline Sulawesi Tenggara & 21 & - & - \\
\hline
\end{tabular}


expenses, poor financial, remote location, cheaper import, poor purchasing power of the population, lack of formal education, culture and tradition, natural and manmade disaster (A.B., 1998); satisfied with their current level of performance and not striving to expand (Cromie et al., 2001); high transport cost, tendency towards oligopoly and imperfect competition, inability to achieve and exploit economies of scale, dearth of effective and competitive support and infrastructural services (Baldacchino, 2005b); government regulation, environment regulation, employment regulation, maintaining profit level (G. Singh, Pathak, \& Naz, 2010) and so many other obstacles.

Based on the background, there are some issues on this study as follows:

1. Based on its competitiveness, conditions in the islands cannot be equated with the mainland. Therefore, it takes more effort to grow and to develop SMIs on an island. Unfortunately, the Government doesn't realize it because they only made one generic policy, strategy, and program to grow and to develop competitive SMIs in Indonesia as stated on RIPIN 20152035 (master plan for the development of national industry, 2015:94);

2. Based on their low competitiveness and so many obstacles facing by SMIs in the islands, the question arises is, how do SMIs in Islands build and sustain their competitive advantage?

\section{METHODS}

For the literature review, we use the deductive reasoning from the previous study to get major constructs of successful small manufacturing industry in the Islands. The stages in selecting journals related to islands entrepreneur are as follows:

1. We used keyword-based search to apply to each prominent paper search engine i.e. google scholar, web of science, emerald and ProQuest and using the following key query words "competitive advantage in the island" along with either "SMEs in the island" and found 61 articles in the English language;
2. Then, from the 61 articles, we select the research sites that are in the islands context only, such as Aland, Iceland, Malta, Saaremaa, Scottish Isles, Fiji, Solomon Island, Cooks Island, Western Samoa, Tonga, Marshall Island, Canary Island Spain, etc. and finally only 24 articles that have a close relation to islands SMEs competitive advantage;

3. From the 24 articles, then we explored the findings of the research, samples, and methods used, and the results shows that there are 12 articles talk about obstacles and challenges faced by the islands entrepreneurs and 12 articles talk about success factors for islands entrepreneurs. and;

4. Finally, complete explanation about current research on islands enterprises, the authors found 12 articles focusing on islands small business competitiveness see Table 2

\section{Islands Characteristics}

An islands is "a country or territory that is completely surrounded by ocean water and countries or territories that are isolated in terms of language, which to some extent would imply cultural isolation" (2008:180) (Aubert \& Chen, 2008). (Mike Danson and Kathryn Burnett, 2014:153) mention that "islands are physically understood as entities set apart from other land mass, and yet each is always bound into a relationship with their relative neighbors of either other islands and/or of mainland". Based on the above definitions, it could be concluded that an islands is surrounded by water, a small unit of land having less population, to some extent quarantined in terms of language and culture but always bound into connection with their relative neighbors. These characteristics are suitable for the islands provinces in Indonesia, whose approximately 85.2 percent of the total area is sea and averagely only 14.8 percent of the total area is land surrounded by averagely 1.203 small islands as shown in table 3.

\section{The Competitive Advantages}

Competitive advantage is a very common term 
Table 2. Source of Small Firms Competitiveness in Islands

\begin{tabular}{|c|c|c|}
\hline No. & Author(s) & Source of Competitiveness \\
\hline 1 & (A.B., 1995) & $\begin{array}{l}4 \text { Most Critical Success Factors : Good Management, Access to financing, } \\
\text { personal qualities and satisfactory government support }\end{array}$ \\
\hline 2 & (Baldacchino, 1998) & $\begin{array}{l}\text { Knowledge based services, Marketing locality (tourist market and diaspora), } \\
\text { manufacturing is best seen as an extension of services, Rent recipients. }\end{array}$ \\
\hline 3 & $\begin{array}{l}\text { (Baldacchino, 2000, } \\
\text { 2002, 2010) }\end{array}$ & $\begin{array}{l}\text { Packaging the paradise myth, utilization of tourism traffic, tourism } \\
\text { industry as export outlet, Totally natural, Price setting strategy, Labour } \\
\text { intensity, Just-in-time production, By-product utilization, Technological } \\
\text { ownership, Financial prudence, Communication supports, Naturalized } \\
\text { entrepreneurship. }\end{array}$ \\
\hline 4 & $\begin{array}{l}\text { (Baldacchino, } \\
\text { 2005b) }\end{array}$ & $\begin{array}{l}\text { Existing Firms acting as Incubators, Competitive Manufactures by ICTs, } \\
\text { Driving Overseas Client Support, Maneuvering as Glocal Citizens, Island } \\
\text { Branding, Targeted External Supports, Seeking \& Securing International } \\
\text { Standards, Professional but Loyal Workforce. }\end{array}$ \\
\hline 5 & $\begin{array}{l}\text { (van Gelder, de } \\
\text { Vries, Frese, \& } \\
\text { Goutbeek, 2007) }\end{array}$ & $\begin{array}{l}\text { More often employ a detailed and long-term planning strategy, set more } \\
\text { specific and more difficult goals, higher degree of human capital (education, } \\
\text { development of skills). }\end{array}$ \\
\hline 6 & $\begin{array}{l}\text { (T. Singh, Pathak, \& } \\
\text { Kazmi, 2007) }\end{array}$ & Management expertise, Marketing ability, Financial management skills \\
\hline 7 & $\begin{array}{l}\text { (Scott, Denize, } \\
\text { Sloan, } \\
\text { \& Sydney, 2005) }\end{array}$ & The ability to secure and activate network relationships, ICT capabilities \\
\hline 8 & $\begin{array}{l}\text { (Gungaphul \& } \\
\text { Boolaky, 2009) }\end{array}$ & $\begin{array}{l}\text { Product offering based on customer needs and wants, talking and listening } \\
\text { to the customers, maintaining close relationship with the customers. }\end{array}$ \\
\hline 9 & (Baldacchino, 2010) & Authenticity and uniqueness, manufacturing experience to the customer \\
\hline 10 & (Ünlücan, 2010) & $\begin{array}{l}\text { Firm flexibility, almost all managers can speak foreign languages because } \\
\text { language can be beneficial in the areas selling and marketing overseas. }\end{array}$ \\
\hline 11 & $\begin{array}{l}\text { (Naidu \& Chand, } \\
\text { 2012) }\end{array}$ & Financial Capabilities \\
\hline 12 & $\begin{array}{c}\text { (Sambajee \& } \\
\text { Dhomun, 2015) }\end{array}$ & $\begin{array}{l}\text { Bootstrapping strategy (utilized their family, peers and professional } \\
\text { networks) }\end{array}$ \\
\hline
\end{tabular}

Table 3. Islands Provinces Characteristics in Indonesia

\begin{tabular}{ccccc}
\hline PROVINCE & SEA AREA (\%) & LAND AREA (\%) & $\begin{array}{c}\text { SMALL ISLANDS } \\
\text { AROUND }^{\mathrm{a}}\end{array}$ & $\begin{array}{c}\text { POPULATION } \\
\text { 2015 }^{\mathrm{b}}\end{array}$ \\
\hline Kepulauan Bangka Belitung & 79,90 & 20,10 & 950 & 1.370 .331 \\
\hline Kepulauan Riau & 96 & 4 & 2408 & 1.968 .313 \\
\hline NTT & 88 & 12 & 1192 & 5.112 .760 \\
\hline NTB & 85 & 15 & 864 & 4.830 .118 \\
\hline Sulawesi Utara & 78,90 & 21,10 & 668 & 2.409 .921 \\
\hline Maluku & 92,96 & 7,04 & 1422 & 1.683 .856 \\
\hline Maluku Utara & 90,80 & 9,20 & 1474 & 1.160 .275 \\
\hline Sulawesi Tenggara & 74,25 & 25,75 & 651 & 2.495 .248 \\
\hline INDONESIA & 64,97 & 35,03 & 17.000 & 255.182 .144 \\
\hline
\end{tabular}

Sources: a. bps.go.id b. (BPS, 2015) 
in the strategic management field. Michael Porter was the first person that coined the term competitive advantage on management strategy terminology. Although it has become a key subject of management strategy, it is still poorly understood (O'Shannassy, 2008). Porter states that "competitive advantage is at the heart of any strategy and achieving competitive advantage requires affirm to make choice about the type of competitive advantage it seeks to attain" (1988:53) (Solem, 1988). Competitive advantage is defined by Smith and Flanagan (2006) as something which distinguishes the company from other companies and makes it alive and growing (Švárová \& Vrchota, 2014). A study by (Cater, 2003) classified
4 (four) basic schools (industrial organization school, resourced based school, capabilitybased school, knowledge-based school) and 2 (two) fundamental forms (cost leadership and differentiation) concerning the source of competitive advantages after conducting a review of literature and an empirical study involving 225 Slovenians firms. The four basic school of competitive advantage are seen in Table 4.

Based on above explanation about four schools of thought in competitive advantage, the authors then trying to make the viability of implementing all four schools of thought in the small manufacturing in island context, see Table 5 .

Table 4. Competitive Advantage School of Thought (Cater, 2003)

\begin{tabular}{|c|c|c|c|}
\hline No. & \multicolumn{2}{|c|}{ School of Thought } & Advocates \\
\hline 1 & external & $\begin{array}{l}\text { Industrial } \\
\text { Organization School }\end{array}$ & $\begin{array}{l}\text { Mason (1939); Bain (1956) Lado, Hansen, Wernerfelt (1989); Porter } \\
(1976,1981,1990) \text {; Boyd, Wright (1992); Gadhoum (1998) }\end{array}$ \\
\hline 2 & internal & $\begin{array}{l}\text { Resourced Based } \\
\text { School }\end{array}$ & $\begin{array}{l}\text { Penrose (1959); Wernerfelt (1984); Barney (1986,1991,1996,); } \\
\text { Mahoney, Pandian (1992); Bharadwaj, Varadarajan, Faky (1993); } \\
\text { Hunt (1999); Cater (2001); Zupun (1996); Michalisin, Smith, Kline } \\
\text { (1997); Whitehill (1997) }\end{array}$ \\
\hline 3 & internal & $\begin{array}{l}\text { Capability-based } \\
\text { school }\end{array}$ & $\begin{array}{l}\text { Snow, Hrebiniak (1980); Prescot, Visscher (1980); Hiit, Ireland } \\
\text { (1985); Ulrich (1987); Collis (1991,1994); Stalk, Evans, Shulman } \\
\text { (1992); Bartmess, Cerny (1993); Day (1994); Tampoe (1994); } \\
\text { Leonard, Barton (1992); Post (1997); Eisendhardt, Martin (2000); } \\
\text { Luo (2000); King, Fowler, Zeithaml (2001) }\end{array}$ \\
\hline 4 & internal & $\begin{array}{l}\text { Knowledge-Based } \\
\text { School }\end{array}$ & $\begin{array}{l}\text { Nonaka, Takeuchi (1995); Edvinsson, Sullivan (1996); Demarest } \\
\text { (1997); Edvinson, Malone (1997); McAulay, Russel, Sims (1997); } \\
\text { Inkpen (1998); Teece (1998); Leonard, Sensiper (1998); Pucko } \\
\text { (1998); Zack (1999) }\end{array}$ \\
\hline & & Fundamentc & l forms: Cost Leadership - Differentiation \\
\hline
\end{tabular}

Table 5. Competitive Advantages school of thought and Islands Appropriateness

\begin{tabular}{llllll}
\hline $\begin{array}{l}\text { School of Thought } \\
\text { /Dimensions }\end{array}$ & Uncertainty & Sustainability & Affordability & Level & $\begin{array}{c}\text { Islands } \\
\text { Appropriateness }\end{array}$ \\
\hline Industrial Based & High & High & Medium & Corporate & Medium \\
\hline Resource Based & Low & Low & High & Business & High \\
\hline Capability Based & Medium to High & High & Medium & Functional & High \\
\hline Knowledge Based & Low to Medium & High & Medium & Corporate & Medium \\
\hline
\end{tabular}


The four school of thoughts are viewed from five dimensions as follows:

1. The first is the uncertainty that expresses of the dynamic changes in the source of competitive advantage when the firm's concerns in this area. For example, if the company focuses on industrial resource based, then the dynamic development of the industry environment makes the company must on the track of these developments if do not want to be left behind. So their resource changing are also very high. Nonetheless, for the resource-based firms, they are less focused on the dynamics of the industrial environment but attempt to exploit the resources they have in their firms. Therefore his uncertainty level is low.

2. The Second is sustainability. The purpose of this dimension is the relationship between the ways companies view the source of competitiveness with the sustainability of the firms in the future. In this case, for example, companies that focus on industrial resources based that always follow the development of market / industrial environment will more likely have a longer industries life cycle. Meanwhile, the firms that focus on resourcebased, then its sustainability will be lower, because they only focus on exploiting their resource without thinking of market changing. While firms that focus on capability based and knowledge based will also likely have the ability to stay longer in the industry. This is because this both approaches are closer to ideal conditions that are often called ambidexterity.

3. The third is affordability. It demonstrates the efforts that firms must "sacrifice' to reach each source of competitiveness based on the four school of thought. The less "sacrifices" that should be made by the company, the more affordable and vice versa.

4. The fourth is level. It shows at which level the four schools of thought are much discussed. For industry-based schools, because they relate to the in which industry firms will compete, then it's more discussed at the corporate level. Then, as mention above, that resource-based school talk about resource selecting, so this approach will be much related to the business strategy which is cost leadership or differentiation. Meanwhile, capability-based school talk about resources deploying, so this approach will be much related to the functional strategy of the firms such as operation, marketing, finance, etc. Then, for knowledge based school, which talks more about human capitals and investments for structural capital, this approach is supposedly more discussed at the corporate level.

5. The last dimension is island appropriateness. It is talk about the suitability of the 4 (four) approaches to the island context. Based on the table, we can conclude that these four approaches are a fairly feasible approach to the island context. All of the school of thought are a complement and enhance each other.

\section{RESULTS AND DISCUSSION}

In this article, the authors look at the compatibility of four school of thought with current research on competitive advantage in small manufacturing industry on islands, as discussed in the literature review table (table 6). From the table, the following conclusions can be drawn:

1. To strengthen the positioning of the firms in the industry environment, some industrial organization schools advocate to targeted external supports such as government or NGO, and implement customer relationship management to build a strong link to the customer and product offering based on customer needs and wants. The utilization of tourism traffic and tourism industry is a big opportunity for islands SMI's since the tourism industry is usually a mainstay for the island. Moreover, Baldacchino, stated that there are 2 (two) sources that will be a great marketing opportunity, which are tourists who come to 
the islands and the diaspora (Baldacchino, 1998).

2. Based on the resource-based school of thought, it is suggested to use local natural raw materials and Islands Branding to emphasize their uniqueness. In addition, this can also be supported by the implementation of just in time inventory, because basically, the firm's production is not too large so that the "opportunity cost" of inventory could be efficient

3. As previously mentioned, capability building mechanism asserts that firms create profit by being effective than their competitors at deploying resources (Makadok, 2001). In order to deploy the resources, some scholars (G. Singh et al., 2010; van Gelder et al., 2007) suggested for small firms in the islands to make clear goals and objectives and set more specific and more difficult goals. The impression is, so far, the small industry is only nature in reactor strategic types (Miles and Snow, 1978) in (María García-Pérez, YanesEstévez, Ramón Oreja-Rodríguez, \& GonzálezDávila, 2014), which is a firm with no clear strategic orientation. ICT (information and communication technology) capabilities have also become one of competitiveness boosters; however, unfortunately, due to the limited infrastructures in the islands, only few scholars focus on this aspect (Cromie et al., 2001). One of the capabilities suggested to be owned by entrepreneurs in the islands is the ability to speak English. As mentioned in some previous school of thoughts, their potential target market is overseas and tourist market as well as for maneuvering as Glocal (global but local) citizens (Baldacchino, 2005b). This can also be the government's concern to organize an English training for potential entrepreneurs in the islands. In contrast to industrial organization school which is expecting government support, (Sambajee \& Dhomun, 2015), found that bootstrapping capabilities (self-reliance) can be done by utilizing family, relatives and professional networking. Based on the literature review, most of the small firms in the islands viewed capability based school of thought as their source of competitiveness.

4. In the knowledge-based school of thought, only (Baldacchino, 2005b) and (van Gelder et al., 2007) mentioned about KnowledgeBased Service and human capital (education, development of skills). This could be a future research opportunity. Knowledge management (KM) is a growing focus in management research because of its role in determining companies' innovation capability and improving the quality of life of the employees (Wang \& Yang, 2016). The problem is that generally small industries face a very dynamic competition environments. On the other hand, their ability and desire to learn are very insignificant especially because of their attitude that is easily satisfied with the present condition. KM Refers to the management of corporate knowledge in a systematic and organizational way to acquire, organize, maintain, apply, share and update the explicit knowledge by employees to improve organizational performance and create value (Davenport \& Prusak, 1998). While resourcebased school became one of the sources to gain competitive advantage, the knowledgebased school could be one source of firm sustainability. According to (Cater, 2004), there are three main tasks of knowledge management: 1) at strategic level, to establish a 'knowledge oriented' mentality in a firm, which means the company has the ability to analyze and plan its business through current knowledge and possessing and knowledge needed for future business processes; 2) at tactical level, to make sure that existing knowledge is correctly acknowledged; and 3) at operational level, employees use that knowledge in daily activities and all employees can access the right knowledge at the right time and at the right location. 
Table 6. the Source of Competitive Advantages for Firms in Islands

\begin{tabular}{|c|c|c|c|c|c|c|c|}
\hline \multicolumn{2}{|c|}{ Industrial Organization School } & \multicolumn{2}{|c|}{ Resourced Based School } & \multicolumn{2}{|c|}{ Capability-based school } & \multicolumn{2}{|c|}{ Knowledge-Based School } \\
\hline \multicolumn{8}{|c|}{ Small Firms in Island } \\
\hline Source of CA & Author(s) & Source of CA & Author(s) & Source of CA & Author(s) & Source of CA & Author(s) \\
\hline $\begin{array}{l}\text { Driving Overseas } \\
\text { Client Support, } \\
\text { Seeking \& } \\
\text { Securing } \\
\text { International } \\
\text { Standards, } \\
\text { Targeted External } \\
\text { Supports } \\
\end{array}$ & $\begin{array}{l}\text { (Baldacchino, } \\
\text { 2005b) }\end{array}$ & $\begin{array}{l}\text { Island } \\
\text { Branding, } \\
\text { romancing the } \\
\text { brand }\end{array}$ & $\begin{array}{l}\text { (Baldacchino, } \\
\text { 2000, 2002, } \\
\text { 2005b) }\end{array}$ & $\begin{array}{l}\text { Maneuvering as } \\
\text { Glocal (global but } \\
\text { local) Citizens, } \\
\text { Professional but } \\
\text { Loyal Workforce }\end{array}$ & $\begin{array}{l}\text { (Baldacchino, } \\
\text { 2005a) }\end{array}$ & $\begin{array}{l}\text { Knowledge } \\
\text { Based } \\
\text { Service }\end{array}$ & $\begin{array}{l}\text { (Baldacchino, } \\
\text { 1998) }\end{array}$ \\
\hline $\begin{array}{l}\text { Government } \\
\text { Support }\end{array}$ & $\begin{array}{l}\text { (A.B., 1995) } \\
\text { (Baldacchino, } \\
\text { 2005b) } \\
\text { (Sambajee \& } \\
\text { Dhomun, 2015) }\end{array}$ & $\begin{array}{l}\text { small-island } \\
\text { "myth" } \\
\text { brand, to } \\
\text { emphasis their } \\
\text { uniqueness }\end{array}$ & $\begin{array}{l}\text { (Scott et al., } \\
2005)\end{array}$ & $\begin{array}{l}\text { Management } \\
\text { expertise, } \\
\text { Marketing ability, } \\
\text { Clear goal and } \\
\text { objectives } \\
\text { Set more specific } \\
\text { and more difficult } \\
\text { goal }\end{array}$ & $\begin{array}{l}\text { (T. Singh et } \\
\text { al., 2007; van } \\
\text { Gelder et al., } \\
\text { 2007) }\end{array}$ & $\begin{array}{l}\text { human } \\
\text { capital } \\
\text { (education, } \\
\text { development } \\
\text { of skills) }\end{array}$ & $\begin{array}{l}\text { (van Gelder } \\
\text { et al., 2007) }\end{array}$ \\
\hline $\begin{array}{c}\text { strong links } \\
\text { with customer } \\
\text { markets, secure } \\
\text { and activate } \\
\text { network } \\
\text { relationships, }\end{array}$ & $\begin{array}{l}\text { (Scott et al., } \\
\text { 2005) }\end{array}$ & $\begin{array}{l}\text { authenticity } \\
\text { and } \\
\text { uniqueness }\end{array}$ & $\begin{array}{l}\text { (Baldacchino, } \\
\text { 2010) }\end{array}$ & $\begin{array}{l}\text { Financial } \\
\text { Capabilities, access } \\
\text { to financing }\end{array}$ & $\begin{array}{l}\text { (A.B., 1995; } \\
\text { Naidu \& } \\
\text { Chand, 2012) }\end{array}$ & & \\
\hline $\begin{array}{l}\text { utilization of } \\
\text { tourism traffic, } \\
\text { Tourism industry } \\
\text { as export outlet, } \\
\text { marketing locality } \\
\text { (tourist market } \\
\text { and diaspora) }\end{array}$ & $\begin{array}{c}\text { (Baldacchino, } \\
\text { 1998, 2000, 2002) }\end{array}$ & $\begin{array}{l}\text { "just in } \\
\text { time"inventory }\end{array}$ & $\begin{array}{l}\text { (Baldacchino, } \\
\text { 2002) }\end{array}$ & $\begin{array}{l}\text { bootstrapping } \\
\text { strategies }\end{array}$ & $\begin{array}{l}\text { (Sambajee } \\
\text { \& Dhomun, } \\
\text { 2015) }\end{array}$ & & \\
\hline \multirow[t]{6}{*}{$\begin{array}{l}\text { Product offering } \\
\text { based on } \\
\text { customer needs } \\
\text { and wants, talking } \\
\text { and listening to } \\
\text { the customers, } \\
\text { maintaining close } \\
\text { relationship with } \\
\text { the customers. }\end{array}$} & $\begin{array}{l}\text { (Gungaphul \& } \\
\text { Boolaky, 2009) }\end{array}$ & $\begin{array}{c}\text { use local } \\
\text { raw material, } \\
\text { Totally natural, } \\
\text { By-product } \\
\text { utilization, } \\
\text { secret recipe }\end{array}$ & $\begin{array}{l}\text { (Baldacchino, } \\
\text { 2000) }\end{array}$ & ICT capabilities & $\begin{array}{l}\text { (Baldacchino, } \\
\text { 2005a; Scott et } \\
\text { al., 2005) }\end{array}$ & & \\
\hline & & & & $\begin{array}{l}\text { Manufacturing } \\
\text { experience to the } \\
\text { customer }\end{array}$ & $\begin{array}{l}\text { (Baldacchino, } \\
\text { 2010) }\end{array}$ & & \\
\hline & & & & $\begin{array}{c}\text { selling products via } \\
\text { the internet }\end{array}$ & $\begin{array}{l}\text { (Baldacchino, } \\
\text { 2002) }\end{array}$ & & \\
\hline & & & & $\begin{array}{l}\text { word-of-mouth } \\
\text { marketing, } \\
\text { Maintaining close } \\
\text { relationship with } \\
\text { customers } \\
\end{array}$ & $\begin{array}{l}\text { (Gungaphul \& } \\
\text { Boolaky, 2009) }\end{array}$ & & \\
\hline & & & & $\begin{array}{c}\text { Good management, } \\
\text { personal qualities, }\end{array}$ & (A.B., 1995) & & \\
\hline & & & & $\begin{array}{c}\text { Firm flexibility, } \\
\text { almost all managers } \\
\text { can speak foreign } \\
\text { languages because } \\
\text { language can be } \\
\text { beneficial }\end{array}$ & $\begin{array}{l}\text { (Ünlücan, } \\
\text { 2010) }\end{array}$ & & \\
\hline
\end{tabular}




\section{MANAGERIAL IMPLICATIONS}

1. For Government and policy makers, the results of this study are expected to be a consideration and concern of the government in making programs and activities for the empowerment of small manufacturing industry in the islands.

2. For management practices, the results of this study are expected to be an example for managers/owners of small manufacturing industries in the islands to build the sustainable competitive advantage for its business. Especially for knowledge based, as the source of competitive advantages which some managers/owners thought is unaffordable for small industries, but actually there is a principle from Japan which is known by the term of $5 \mathrm{~S}$, i.e. Seiri (the willingness to reach a goal), Seiton (put things in order), Seiso (earn the esteem and respect of both peers and superiors), Seiketsu (maintain self-composure), and Shitsuke (build and maintain self-discipline) (Jaca, Viles, PaipaGaleano, Santos, \& Mateo, 2014), that could organize people on the organization to develop and share the knowledge, especially tacit knowledge. In Indonesia the term is often recognized by the term of $5 \mathrm{~K}$, i.e. Kerapihan (sorting items according to its function and place), Keteraturan (arrange the equipments to reduce searching time), Kebersihan (cleanliness to increase productivity), Kelestarian (familiarization, with the rules or firm culture), and Kedisiplinan (consolidation, usually by making standard operating procedure).

\section{CONCLUSION}

1. There are only a few researchers concern with R\&D, competitors, accounting, suppliers, and knowledge based school of thought of competitive advantage as the sources of competitive advantage in a firm in the islands context. Moreover, based on the papers above, less scholars develop normative model/theory on their research. Explore more about this concept that is affordable for small industries are promising future research opportunities.

2. Based on its competitiveness, conditions in the island regions cannot be equated with the mainland, therefore it takes more effort to grow and to develop SMIs on an island. Unfortunately, the Government doesn't realize it because they only made one generic policy, strategy, and program to grow and to develop competitive SMIs in Indonesia as stated on RIPIN 2015-2035 (master plan for development of national industry, 2015:94).

3. For operation strategy, small manufacturing firm in island use local raw material, totally natural, secret recipe (Baldacchino, 2000), flexibility in product quantity, types and delivery (Gungaphul \& Boolaky, 2009; Ünlücan, 2010), set clear goals and objectives (T. Singh et al., 2007; van Gelder et al., 2007), and ICT capabilities (Baldacchino, 2005a; Scott et al., 2005). For marketing strategy, small manufacturing industry in island do an island branding, authenticity and uniqueness (Baldacchino, 2000, 2002, 2005b, 2010), small island myth brand (Scott et al., 2005), driving overseas client support (Baldacchino, 2005a), utilization of tourism traffic (Baldacchino, 1998, 2000, 2002), word of mouth marketing, maintaining close relationship with the customers (Gungaphul \& Boolaky, 2009). For Human resources development, small manufacturing in islands maneuvering their human resources as Glocal (global but local) citizens, professional but loyal workforce (Baldacchino, 2005a), bootstrapping strategy (Sambajee \& Dhomun, 2015), organization innovation intensity, education and development of skills (van Gelder et al., 2007), good management, management expertise, personal qualities (A.B., 1995). For finance and accounting strategy, small manufacturing industry in islands implement cost management practices, and the firms record their manufacturing costs separately in their accounts, cost accounting practices 
to measure the manufacturing costs, as well as access to financing (A.B., 1995; Naidu \& Chand, 2012) and rent recipient (Baldacchino, 1998).

4. There are few studies focusing on the knowledge-based school of thought for the small manufacturing industry in the islands although knowledge-based school approach is very important for sustainability, but the challenge for small manufacturing is its affordability. Studying 5W $1 \mathrm{H}$ (what, where, why, when, who and how) of this approach in competitive small manufacturing industry will fill the gap of the area of research.

5. The main challenge for small manufacturing in the islands with regard to knowledge-based school is human resources. Because they are usually low-educated, their ability to find and solve problems is low. Similarly, their structural capital is also low. If we use the analogy of hierarchy needs, knowledge management or research and development focusing on human capital and structural capital may be too high for small industries. This might also be one of their weaknesses in terms of innovation. Because of this aspect, only few researchers discuss it in their research. In fact, these practices can be an affordable approach for small industries through such an approach as the quality control circle or a $5 \mathrm{~S}$ approach (Seiri, Seiton, Seiso, Seiketsu, and Shitsuke) from Japan. .

Acknowledgement:

I acknowledge Kepulauan Bangka Belitung Provincial Government, which fully supported for this research.

\section{REFERENCES}

A.B., Y. (1995). Critical success factors for small business: perceptions of South Pacific entrepreneurs. Journal of Small Business Management, 33(2), 68-73.

A.B., Y. (1998). Small business development and survival in the south pacific: Barriers and strategic responses. Journal of Entrepreneurship, 7(1), 49-65.

Aubert, J., \& Chen, D. H. C. (2008). The island factor as a growth booster for nations: a mental advantage econometrically revealed. Journal of Intellectual Capital, 9(2), 178-205.

Baldacchino, G. (1998). The other way round: manufacturing as an extension of services in small island states. Asia Pacific Viewpoint, 39(3), 267-279.

Baldacchino, G. (2000). An exceptional success manufacturing firm in a small island country. The Journal of Pasific Studies, $23(1), 27-47$.

Baldacchino, G. (2002). A Taste of Small-Island Success : A Case from Prince Edward Island. Journal of Small Business Management, 40(3), 254-259.

Baldacchino, G. (2005a). Island entrepreneurs: Insights from exceptionall successful knowledge-driven SMEs from 5 European island territories. Journal of Enterprising Culture, 13(2), 145-170.

Baldacchino, G. (2005b). Successful Small-Scale Manufacturing: a Comparative Assessment Across Five European Island Regions *. Bank of Valletta Review, (31), 17-31.

Baldacchino, G. (2010). Islands and beers: Toasting a discriminatory approach to small island manufacturing. Asia Pacific Viewpoint, 51(1), 61-72.

BPS. (2015). Penduduk Indonesia Hasil Survei Penduduk Antar Sensus 2015.

Cater, T. (2003). The relevance of four school of thought on the sources of a firm's competitive advantage: a case of slovenian firms. Economic and Business Review, 5(4), 309-332.

Cater, T. (2004). The relevance of the knowledge-based school of thought on the sources of a firm's competitive advantage. Management, 9(1), 1-26. 
Cromie, S., Dunn, B., Sproull, A., \& Chalmers, D. (2001). Small firms with a family focus in the Scottish Highlands and Islands. Irish Journal of Management, 22, 45-66.

Davenport, T. H., \& Prusak, L. (1998). Working Knowledge: How Organizations Manage What They Know. Knowledge Creation Diffusion Utilization, 309. https://doi.org/10.1109/EMR.2003.1267012

Gungaphul, M., \& Boolaky, M. (2009). Entrepreneurship and marketing: an exploratory study in Mauritius. Journal of Chinese Entrepreneurship, 1(3), 209-226.

Jaca, C., Viles, E., Paipa-Galeano, L., Santos, J., \& Mateo, R. (2014). Learning 5S principles from Japanese best practitioners: Case studies of five manufacturing companies. International Journal of Production Research, 52(15), 4574-4586.

Makadok, R. (2001). Toward a synthesis of the resource based and dynamic capability views of rent creation. Strategic Management Journal, 22(5), 387-401.

María García-Pérez, A., Yanes-Estévez, V., Ramón Oreja-Rodríguez, J., \& González-Dávila, E. (2014). Strategic positioning and strategic types of small firms. Journal of Small Business and Enterprise Development, 21(3), 431-449.

Mike Danson and Kathryn Burnett. (2014). Exploring Rural Enterprise: New Perspectives on Research, Policy \& Practice, 4.

Naidu, S., \& Chand, A. (2012). A comparative study of the financial problems faced by micro, small and medium enterprises in the manufacturing sector of Fiji and Tonga. International Journal of Emerging Markets, 7(3), 245-262.

O'Shannassy, T. (2008). Sustainable competitive advantage or temporary competitive advantage. Journal of Strategy and Management, 1(2), 168-180.

Sambajee, P., \& Dhomun, M. Z. A. (2015). Government and SMEs in the Maldives and Mauritius. International Journal of Entrepreneurial Behavior \& Research, 21(6), 778-795.

Scott, N., Denize, S., Sloan, T., \& Sydney, W. (2005). Internationally competitive firms in small island developing states: Why do they succeed? Nick Scott, Sara Denize, Terry Sloan, University of Western Sydney, 1-7.

Singh, G., Pathak, R. D., \& Naz, R. (2010). Issues faced by SMEs in the internationalization process: results from Fiji and Samoa. International Journal of Emerging Markets, 5(2), 153-182.

Singh, T., Pathak, R., \& Kazmi, a. (2007). An empirical study of small business organizations in Fiji using a competency-based framework. South Asian Journal of Management, 14(2), 7-35.

Solem, M. P. S. and O. (1988). Factors for Success in Small Manufacturing Firms. Journal of Small Business Management, 26(1), 6 .

Švárová, M., \& Vrchota, J. (2014). Influence of Competitive Advantage on Formulation Business Strategy. Procedia Economics and Finance, 12(March), 687-694.

Than, K.G., Amri, M., Merdikawati, N \& Ahmad, N (2017): 2015 Annual Competitiveness Analysis and Development Strategies for Indonesian Provinces, Singapore: World Scientific Publishing

Ünlücan, D. (2010). Characteristics of SMEs in North Cyprus: A small island. Problems and Perspectives in Management, 8(3), $139-147$.

van Gelder, J.-L., de Vries, R. E., Frese, M., \& Goutbeek, J.-P. (2007). Failed and Operational Business Owners. Journal of Small Business Management, 45(3), 388-400.

Wang, M.-H., \& Yang, T.-Y. (2016). Investigating the success of knowledge management: An empirical study of small- and medium-sized enterprises. Asia Pacific Management Review, 21(2), 79-91.

\section{References from website:}

Nasional kontan. (2017, March 2). Islands provinces in Indonesia, retrieved from Source:http://nasional.kontan.co.id/news/ provinsi-kepulauan-akan-terima-dau-lebih-besar; accessed on: Thursday, March 02, 2017, 8:39:09 AM 